\title{
Taxonomic heterogeneity, as shown by siderotyping, of strains primarily identified as Pseudomonas putida
}

\author{
Correspondence \\ Jean-Marie Meyer \\ meyer@gem.u-strasbg.fr
}

\author{
Jean-Marie Meyer, ${ }^{1}$ Christelle Gruffaz, ${ }^{1}$ Topi Tulkki ${ }^{1}$ and Daniel Izard ${ }^{2}$ \\ ${ }^{1}$ Département Génétique Moléculaire, Génomique, Microbiologie, UMR 7653, Université \\ Louis-Pasteur, 28 rue Goethe, 67000-Strasbourg, France \\ ${ }^{2}$ Service de Microbiologie, Faculté de Pharmacie, 3 rue du Professeur Laguesse, BP 83, \\ 59006 Lille Cedex, France
}

One hundred and forty-four fluorescent pseudomonad strains isolated from various environments (soil, water, plant rhizosphere, hospital) and received as Pseudomonas putida (83 strains), $P$. putida biovar A (49 strains), P. putida biovar B (10 strains) and $P$. putida biovar C (2 strains), were analysed by the pyoverdine-isoelectrofocusing and pyoverdine-mediated iron uptake methods of siderotyping. Both methods demonstrated a great diversity among these strains, which could be subdivided into 35 siderovars. Some siderovars specifically included strains that have subsequently been transferred to well-defined Pseudomonas species, e.g. Pseudomonas monteilii or Pseudomonas mosselii, or which could be related by their siderotype to Pseudomonas jessenii or Pseudomonas mandelii. Other siderovars included strains sharing a high level of DNA-DNA relatedness $(>70 \%)$, thus demonstrating that siderotyping could easily circumscribe strains at the species level. However, a group of seven strains, including the type strain, P. putida ATCC $12633^{\top}$, were allocated into four siderovars, despite sharing DNA-DNA relatedness values of higher than $70 \%$. Interestingly, the strong genomic relationships between these seven strains were supported by the structural relationships among their pyoverdines, thus reflecting their phylogenetic affinities. These results strongly support the view that pyoverdine-based siderotyping could be used as a powerful tool in Pseudomonas taxonomy.

\section{INTRODUCTION}

Although some reports have described Pseudomonas putida as an opportunist human pathogen associated with clinical infections, particularly among children (Bouallegue et al., 2004; Perz et al., 2005), this species is usually considered as an innocuous environmental micro-organism with a significant potential for biotechnological applications due to its metabolic versatility and great environmental adaptability (Timmis, 2002). Widely distributed in soil and water, $P$. putida thrives in highly polluted environments where it may actively participate in bioremediation processes. The importance of $P$. putida, as well as other ubiquitous soil-borne pseudomonads, e.g. Pseudomonas fluorescens or Pseudomonas stutzeri, has generated many ecological and environmental studies that have required numerous attempts to identify strains and have often faced many difficulties due to the great diversity encountered within these species (Palleroni, 1993; Moore et al., 1996; Anzai et al., 2000).

Abbreviations: bv., biovar; $\mathrm{pH}$, isoelectric $\mathrm{pH}$; PVD, pyoverdine; PVD-IEF, pyoverdine-isoelectrofocusing; sv., siderovar.
The taxonomic heterogeneity of $P$. putida was the basis for the characterization of two biovars, A and B (Stanier et al., 1966; Palleroni, 1984, 2005), and the minor biovar, C (Barrett et al., 1986). While recent methods have demonstrated high efficiency in Pseudomonas identification, with assays specific to Pseudomonas at the genus level or specific to a single species (i.e. Pseudomonas aeruginosa, Spilker et al., 2004), the present status of the fluorescent saprophytic members of the genus Pseudomonas is not satisfactory. In particular, there is a consensus among taxonomists that $P$. fluorescens and $P$. putida should be considered as very heterogeneous species which each need to be divided into several nomenspecies (Bossis et al., 2000). Together with the pioneering work of Stanier, Palleroni and Doudoroff (Stanier et al., 1966), many other studies based on biochemical characteristics (Grimont et al., 1996), wholecell protein analysis (Tesar et al., 1996; Vancanneyt et al., 1996), 16S rRNA gene sequence comparisons (Moore et al., 1996) or involving both phenotypic and genomic typing approaches, e.g. Biolog metabolic profiling, restriction fragment length polymorphism ribotyping, PCR ribotyping, repetitive element sequence-based PCR (rep-PCR), using $\mathrm{BOX}$ or enterobacterial repetitive intergenic consensus 
(ERIC) primers (Brosch et al., 1996; Dawson et al., 2002), effectively concluded that great taxonomic heterogeneity was the rule within the species $P$. fluorescens and P. putida. The need for a detailed revision at the biochemical and molecular levels was also shown by a combined dataset of four molecular sequences ( $a t p D, \operatorname{carA}, \operatorname{rec} A$ and 16S rRNA gene sequences; Hilario et al., 2004) and by sequence comparisons focused on gyrB and $r p o D$ gene sequences (Yamamoto et al., 2000). Interestingly, all these studies, as well as a few others specifically focused on $P$. putida (Yamamoto \& Harayama, 1995, 1998), concluded that $P$. putida strains belonging to biovar B are phylogenetically closer to P. fluorescens strains than to strains of $P$. putida biovar A.

A great diversity also exists at the level of the pyoverdines, the main siderophores produced by the fluorescent members of the genus Pseudomonas (Meyer, 2000). Well known as the yellow-green fluorescent pigments which characterize these bacteria, pyoverdine molecules are mainly composed of a quinoline-based chromophore associated with a peptide chain and an acyl side chain (see Budzikiewicz, 2004 for details). The amino acid composition of the peptide chain varies greatly depending on the producing strain, while the chromophore is well conserved among strains. The acyl side chain can also vary within a limited range of dicarboxylic compounds, e.g. succinic acid and malic acid and their amides, or $\alpha$ ketoglutaric acid for the most frequently distributed ones, resulting in several isoforms of an otherwise identical pyoverdine produced by a given strain (Budzikiewicz, 2004). Based on the peptide chain diversity which takes into account the number and types of amino acyl residues, with the presence of L- and D-forms arranged in linear or partially cyclic chains, close to 50 different pyoverdine structures have been recognized to date. Twelve of these structures have been isolated from strains belonging to the species $P$. putida and 22 have been isolated from $P$. fluorescens strains (Budzikiewicz, 2004).

With the development of siderotyping methods and their application to numerous strains to give an easy and fast discrimination of the pyoverdines they produce, it soon became evident that pyoverdines are not only powerful siderophores but are also efficient taxonomical markers for fluorescent pseudomonads. As a general rule, strains belonging to a given species produce an identical pyoverdine, whereas strains belonging to different species produce different pyoverdines (Meyer, 2000; Bultreys et al., 2001; Meyer et al., 2002; Meyer \& Geoffroy, 2004). To be valid, however, this rule should also apply to well-defined species, i.e. species defined by a polyphasic taxonomic approach (Vandamme et al., 1996). Effectively, within the taxonomically heterogeneous species $P$. fluorescens, it has already been well established that 28 strains belonging to biovar I are divided into 10 siderovars, thus supporting the heterogeneity of the $P$. fluorescens species and also demonstrating that biovars do not represent a valid, clear-cut taxonomy for these bacteria (Meyer et al., 2002).
The goals of the present study were, firstly, to analyse the diversity of strains assigned to the P. putida species through siderotyping and, secondly, to establish that strain grouping into siderovars is of taxonomical value for these bacteria and could result in the proposal of novel Pseudomonas species.

\section{METHODS}

Pseudomonas putida isolates and reference strains. Most of the strains used in the present study (listed in Table 1) were obtained from several laboratories where they had been phenotypically characterized as belonging to the species Pseudomonas putida. For some strains, characterization was done by the use of a restricted panel of physiological and biochemical characters, allowing the recognition of strains at the biovar level (Palleroni, 1984, 2005; Bossis et al., 2000). For the others, commercially available galleries and treatment of the data by numerical taxonomy were the main means of identification (Elomari et al., 1994). Two phenotypic clusters analysed at the Laboratoire de Bactériologie, Faculté de Médecine, Lille, France, and further characterized by a polyphasic approach as Pseudomonas monteilii and Pseudomonas mosselii (Elomari et al., 1997; Dabboussi et al., 2002), were included in the present study as the majority of the isolates, which were all of medical origin, were first identified as $P$. putida. The other strains were isolated from soil, water or from the rhizospheres of various plants (Table 1).

Growth conditions. For routine cultures, strains were grown in a rich medium comprising $\left(1^{-1}\right)$; $10 \mathrm{~g}$ peptone (Difco), $5 \mathrm{~g}$ beef extract (Difco) and $5 \mathrm{~g} \mathrm{NaCl}$. For bacterial purity control, strains were grown on plates in the same medium supplemented with $12 \mathrm{~g}$ agar (Difco). Iron-deficient cultures were prepared using Casamino acid (CAA) medium containing $\left(1^{-1}\right) ; 5 \mathrm{~g}$ Casamino acids with low iron and chloride content (Difco), $1.18 \mathrm{~g} \mathrm{~K}_{2} \mathrm{HPO}_{4}$ and $0.25 \mathrm{~g} \mathrm{MgSO}_{4} \cdot 7 \mathrm{H}_{2} \mathrm{O}$. Strains grown on iron-deficient media were used for the production and purification of pyoverdines and for their analysis through isoelectrophoresis. For iron uptake studies, iron-deficient cells were harvested from cultures in succinate medium (Meyer et al., 1997). Cultures were incubated at $25{ }^{\circ} \mathrm{C}$ for $40 \mathrm{~h}$ with vigorous shaking (200 r.p.m.) in autoclave-sterilized capped test tubes $(180 \times 18 \mathrm{~mm})$ containing $7.5 \mathrm{ml}$ medium or in Erlenmeyer flasks (50 or $500 \mathrm{ml}$ medium in $250 \mathrm{ml}$ or 11 flasks, respectively). Strains were preserved at $-80{ }^{\circ} \mathrm{C}$ as a mixture of $0.5 \mathrm{ml}$ rich medium liquid culture reaching the end of the exponential phase and the same volume of sterilized glycerol/ $\mathrm{H}_{2} \mathrm{O}$ solution $(50 \%, \mathrm{v} / \mathrm{v})$.

Siderotyping by isoelectrophoresis. A $1 \mathrm{ml}$ sample of a $40 \mathrm{~h}$ CAA-culture at $25{ }^{\circ} \mathrm{C}$ of each P. putida isolate was harvested and centrifuged in an Eppendorf tube for $5 \mathrm{~min}$ at 13000 r.p.m. A $0.4 \mathrm{ml}$ sample of the supernatant was then lyophilized and the residue resuspended in $20 \mu \mathrm{l}$ ultrapure $\mathrm{H}_{2} \mathrm{O}$. A $1 \mu$ l sample of the 20 -fold concentrated culture supernatant containing the various pyoverdine (PVD) isoforms accumulated during bacterial growth was analysed on ampholine-containing polyacrylamide gels as described by Fuchs et al. (2001). The respective pyoverdine-isoelectrofocusing (PVD-IEF) patterns were visualized under UV-illumination at $365 \mathrm{~nm}$. For each strain, the fluorescent PVD-bands representing the different isoforms of an otherwise identical pyoverdine (Fig. 1; Budzikiewicz, 2004) were further computer-analysed for isoelectric $\mathrm{pH}(\mathrm{pHi})$ determination using a standard mixture of pyoverdines as described by Fuchs et al. (2001). A schematic representation of PVD-bands by $\mathrm{pHi}$-bars was then constructed, with bar thicknesses proportional to the intensity of fluorescence of the PVD-bands, as represented in Tables 2, 3 and 4. Systematically, strains presenting identical or closely related PVD-IEF patterns were subjected to a second analysis, including new cultures 


\section{Table 1. Strains used in the study}

With the exception of the reference strains, all strains were primarily identified as Pseudomonas putida and are presently still recognized as such, except those which have been reclassified as Pseudomonas monteilii (Elomari et al., 1997) or as Pseudomonas mosselii (Dabboussi et al., 2002). CFBP, Collection Française de Bactéries Phytopathogènes; CFML, Collection de la Faculté de Médecine de Lille; ATCC, American type Culture Collection; DSM, Deutsche Sammlung von Mikroorganismen.

\begin{tabular}{|c|c|c|c|}
\hline Source & Strain designation & Origin & Reference \\
\hline $\begin{array}{l}\text { INRA-Angers (CFBP) } \\
\text { Gardan-Bossis (GB) } \\
\text { collection }\end{array}$ & $\begin{array}{l}\text { Pseudomonas putida CFBP/GB 11302,11341, 11342, } \\
\text { 11349, 11366, 11370, 11378, 11379, 11384, 11385, } \\
\text { 11387, 11388, 11391, 11394, 11395, 11399 }\end{array}$ & $\begin{array}{l}\text { Plant rhizosphere } \\
\text { (tomato, maize) }\end{array}$ & Bossis (1995) \\
\hline $\begin{array}{l}\text { INRA-Angers (CFBP) } \\
\text { Gardan-Mattar (GM) } \\
\text { collection }\end{array}$ & $\begin{array}{l}\text { Pseudomonas putida CFBP/GM 10090, 10096, 11274, } \\
\text { 11275, 11277, 11797, 11799.1, 11799.2, 11802, 11804, } \\
\text { 11806, 11907, 11908, 11911, 11912, 11916, 11917, 12220 }\end{array}$ & Plant rhizosphere & Mattar (1993) \\
\hline $\begin{array}{l}\text { INRA-Dijon Lemanceau } \\
\text { collection }\end{array}$ & $\begin{array}{l}\text { Pseudomonas putida C-S111, C-S413, C-S215, C-LRp214, } \\
\text { D-S1026, D-LR223, D-S824, D-LR228, D-TRP621, } \\
\text { D-LE3216, D-S131, D-TR331, D-LRp414, D-LRp212, } \\
\text { D-LE611, D-LRp511, D-LE414 J, D-TR1035, D-TE612, } \\
\text { D-LE711, D-LRp921, L1 }\end{array}$ & $\begin{array}{l}\text { Soil or plant } \\
\text { rhizosphere } \\
\text { (tomato, flax) }\end{array}$ & $\begin{array}{l}\text { Lemanceau et al. (1995); } \\
\text { Latour et al. (1996) }\end{array}$ \\
\hline Japan collection & $\begin{array}{l}\text { Pseudomonas putida A10L, BH, PpG7 (=ATCC 17485), } \\
\text { K23-1, KF715, PB4 }\end{array}$ & Miscellaneous & $\begin{array}{l}\text { Yamamoto \& Harayama } \\
\text { (1998) }\end{array}$ \\
\hline Belgium collection & $\begin{array}{l}\text { Pseudomonas putida PGSB8508, PGSB8301, BW13M1, } \\
\text { BW16M1, BW16S1, RW5S2, BW11P1, BW11P2, } \\
\text { BW11M1, RW10S1, GR12-2R3 }\end{array}$ & $\begin{array}{l}\text { Maize, rice, } \\
\text { banana, grass }\end{array}$ & Parret \& De Mot (2000) \\
\hline Miscellaneous & $\begin{array}{l}\text { Pseudomonas putida ATCC } 12633^{\mathrm{T}} \text {, ATCC 39167, DSM } \\
\text { 3601, DSM 3602, MF6313, MFH2-127, PutC, BTP1, } \\
\text { BTP16, WCS358, KT2440, 9BW, 10CW, Gwose }\end{array}$ & & $\begin{array}{l}\text { ATCC and DSM collections; } \\
\text { Jacques et al. (1995); Shivaji } \\
\text { et al. (1989); Timmis (2002) }\end{array}$ \\
\hline Reference strains & $\begin{array}{l}\text { Pseudomonas jessenii CFML } 95-307^{\mathrm{T}} \text {; Pseudomonas mandelii } \\
\text { CFML } 95-303^{\mathrm{T}} \text {; Pseudomonas fluorescens ATCC } 13525^{\mathrm{T}} \text {; } \\
\text { Pseudomonas sp. A214; Pseudomonas sp. B10 }\end{array}$ & & $\begin{array}{l}\text { Verhille et al. (1999); Teintze } \\
\text { et al. (1981); Buyer et al. } \\
\text { (1986) }\end{array}$ \\
\hline
\end{tabular}

and isoelectrophoresis, but with comigration of the samples on the same gel for a better visual control of relatedness. Strains presenting identical PVD-IEF patterns were grouped in a so-called IEF-group. For clarity, Table 2 was built with IEF-groups characterized by PVDbands with acidic pHi values (from 3.9 to 6.0), Table 3 with IEFgroups having PVD-bands at neutral $\mathrm{pHi}$ values (below $\mathrm{pH}$ 8.0) with very often at least one supplementary band at an acidic $\mathrm{pH}$ value, while Table 4 contained the IEF-groups showing IEF bands at neutral and alkaline pHi values.

Siderotyping by pyoverdine-mediated ${ }^{59} \mathrm{Fe}$-uptake. Iron-deficient cells harvested by centrifugation from a $40 \mathrm{~h}$ culture in succinate medium at $25{ }^{\circ} \mathrm{C}$ were washed and resuspended just before use in an incubation medium made of succinate medium without a nitrogen source. The suspension was adjusted to an $\mathrm{OD}_{600}$ of 0.33 and $1.8 \mathrm{ml}$ aliquots were used for each assay. The label mixture containing ${ }^{59} \mathrm{Fe}-$ PVD complex consisted of $5 \mu$ l commercial ${ }^{59} \mathrm{Fe}^{3+}$ solution (iron chloride in $0.1 \mathrm{M} \mathrm{HCl}$; specific activity, $110-925 \mathrm{MBq} \mathrm{mg}^{-1}$ iron; Amersham, France) diluted first with $100 \mu \mathrm{l}$ of distilled water and then mixed with $100 \mu \mathrm{l}$ of pyoverdine-containing succinate culture supernatant. After $10 \mathrm{~min}$ incubation at room temperature, the final volume of label mixture was adjusted to $1 \mathrm{ml}$ with incubation medium. The uptake assay was begun by the addition of $0.2 \mathrm{ml}$ label mixture to $1.8 \mathrm{ml}$ cell suspension and the sample was incubated in a water bath at $30{ }^{\circ} \mathrm{C}$ with gentle shaking for $20 \mathrm{~min}$. Following this, a $1 \mathrm{ml}$ sample was withdrawn and rapidly filtered through a nitrocellulose filter $(0.45 \mu \mathrm{m}$ pore size), which was then washed twice with incubation medium. The filter was wrapped in aluminium foil and counted for radioactivity in a counter (Gammamatic 4000; Beckman). The remaining $1 \mathrm{ml}$ bacterial suspension was directly counted to determine the total amount of radioactivity present in the assay. A control assay without cells was performed for each label mixture in order to verify the complete solubilization of the iron through PVD complexation. Each strain was tested for iron incorporation mediated by its own pyoverdine to evaluate its $100 \%$ efficiency in iron uptake and also for iron incorporation mediated by the pyoverdine of the type strain of the group (in bold typeface in Tables 2, 3 and 4). Strains presenting an identical PVD-IEF pattern and presenting cross-incorporations at $100 \pm 15 \%$ efficiency were considered as producing identical pyoverdines and thus were grouped into siderovars, according to the definition given in Meyer et al. (2002). In most cases, a precise correlation was observed between PVD-IEF groups and siderovars. There were some exceptions, as described in the Results section. Therefore, a second method for 

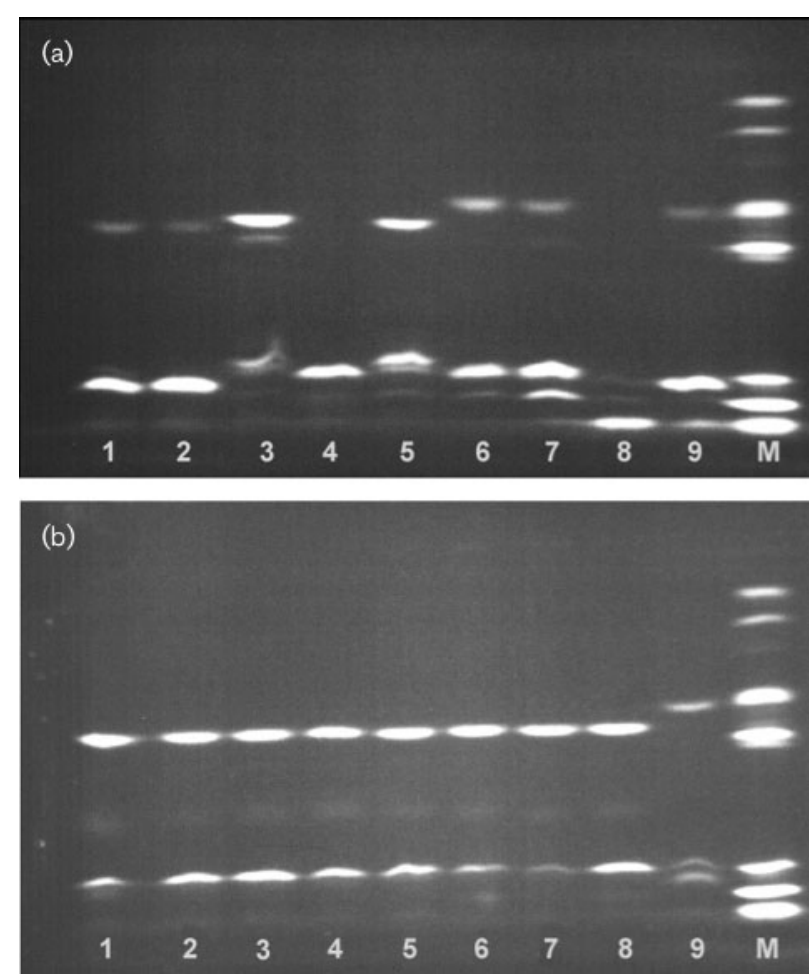

Fig. 1. Pyoverdine-isoelectrophoresis patterns of Pseudomonas putida strains belonging to various siderovars as shown on ampholine-containing polyacrylamide gels photographed under UV-light (365 nm). (a) Lanes: 1, KF715 (sv. 17); 2, CFML 90-44 (sv. 17); 3, GM11917 (sv. 15); 4, GM11277 (sv. 1); 5, L1 (sv. 20); 6, GM11799.1 (sv. 21); 7, GM11799.2 (sv. 21); 8, BTP16 (sv. 2); 9, GS 12065 (sv. 24); M, pyoverdine standard for $\mathrm{pHi}$ measurement (Fuchs et al., 2001). (b) Lanes: 1, GS 12019 (sv.16); 2, GS 12048 (sv. 16); 3, GS 12062 (sv. 16); 4, GS 12081 (sv. 16); 5, GS 12090 (sv. 16); 6, GS 12055 (sv. 18); 7, GB11341 (sv. 18); 8, GB11342 (sv. 18); 9, GB11394 (sv. 23); $\mathrm{M}$, pyoverdine standard as in (a).

validating the strain grouping was to test the type strains with the pyoverdines that had the same acidic, neutral or alkaline behaviours. When such heterologous uptakes occurred, they are shown in the right hand panels of Tables 2, 3 and 4 as the percentage of efficiency of iron incorporation compared with that of the homologous pyoverdine $(100 \%)$. A third class of pyoverdine-mediated iron uptake experiment was to test the type strain of each siderovar against a collection of pyoverdines with well-established structures and/or species assignations (the 36 pyoverdines listed in Fuchs et al., 2001). Such incorporation studies determined whether a particular pyoverdine characterizing a siderovar was a new representative or whether it corresponded to an already structurally-known pyoverdine.

DNA preparation and DNA-DNA hybridization. Chromosomal DNA was extracted, purified and labelled in vitro with $\left[{ }^{3} \mathrm{H}\right]$ cytosine by nick translation as described previously (Elomari et al., 1996). The procedure used for hybridization experiments ( $\mathrm{S} 1$ nuclease-trichloroacetic acid method) has been previously described (Grimont et al., 1980). The determination of $T_{\mathrm{m}}$ (melting temperature) and $\Delta T_{\mathrm{m}}$ (difference between the $T_{\mathrm{m}}$ of the heteroduplex and $T_{\mathrm{m}}$ of the homoduplex) was performed as described in Crosa et al. (1973).

\section{RESULTS AND DISCUSSION}

\section{Strains grouping according to PVD-IEF patterns and pyoverdine-mediated iron uptake}

As illustrated in Fig. 1, the PVD-IEF patterns of P. putida isolates showed great heterogeneity. Among the nine strains analysed in Fig. 1a, at least six different patterns could be easily identified, as seen in lanes $1,3,4,6,8$ and 9 . The differences were due to the number of PVD-bands (corresponding to different PVD-isoforms; Fuchs et al., 2001), with some strains apparently producing a unique PVD-isoform (e.g. lanes 4 and 8), while most strains showed three bands and a few others showed two bands (e.g. lanes 1 and 2). The IEF patterns could also vary according to the fluorescence intensity of the PVD-bands, which reflected the concentration of isoforms present in the culture supernatants. As seen by direct observation, the PVD-patterns of lanes 1 and 2 looked strictly identical, as did those of lanes 6 and 7 except that the intensity of the lower band was brighter in lane 7 compared with lane 6 . Thus, electrophoresis analysis suggested the grouping of strains KF715 and CFML 90-44, corresponding to lanes 1 and 2, while the grouping of strains GB11799.1 and GB11799.2 (lanes 6 and 7) was performed with some degree of uncertainty. To determine whether or not the pyoverdines of strains GB11799.1 and GB11799.2 were identical, iron uptake studies were performed using ironstarved cells of both strains and their respective pyoverdines liganded to ${ }^{59} \mathrm{Fe}$. Both strains were able to incorporate and cross-incorporate labelled iron at $100 \%$ efficiency (data not shown). On this basis, therefore, they were grouped in the same siderovar. The necessity of using the siderophore-mediated iron incorporation method as an adjunct to the IEF method is even better illustrated in Fig. 1b, where eight strains (lanes 1-8) presented apparently identical PVD-IEF profiles. However, crossincorporation studies clearly demonstrated that the eight strains were divided into two subgroups. The first five strains (lanes 1-5) cross-reacted efficiently with each other, as did the three other strains (lanes 6-8), but there was no cross-reactivity detectable between strains belonging to the two subgroups (Table 3 ). Thus, although presenting very close if not identical PVD-IEF patterns, these strains should synthesize structurally different pyoverdines and consequently they were assigned to two different siderovars (sv. 16 and sv. 18 in Table 3). Most of the other PVD-IEF groups, however, presented sufficient IEF-pattern differences from each other to allow correct strain groupings. These groupings were also supported by uptake studies, as shown in Tables 2, 3 and 4. Only three isolates, CFML 9059, CFML 90-60 and CFML 90-61 of siderovar 14 in Table 3 were defective in pyoverdine synthesis and thus could not be analysed by isoelectrofocusing. Their grouping, at least for two of them (isolates CFML 90-59 and CFML 90-61), could, however, be determined by iron incorporation studies. Only the pyoverdine characterizing siderovar 14 was used by the two strains (Table 3). Strain CFML 90-60 
Table 2. Pseudomonas putida strains producing acidic pyoverdines and grouped into siderovars according to PVD-IEF profiles and PVD-mediated iron uptake specificity

Some non-P. putida reference strains have been included. They are indicated by brackets. P. fl., P. fluorescens; P. j., P. jessenii; P. m., P. mandelii; P. sp., Pseudomonas sp. Biovar assignation, if known, is indicated by the letter code A, B or C. PVD-pHi values of the PVD-isoform bands separated by isoelectrophoresis are indicated as bars with thickness proportional to the intensity of fluorescence demonstrated under UV-light illumination (see Fig. 1).

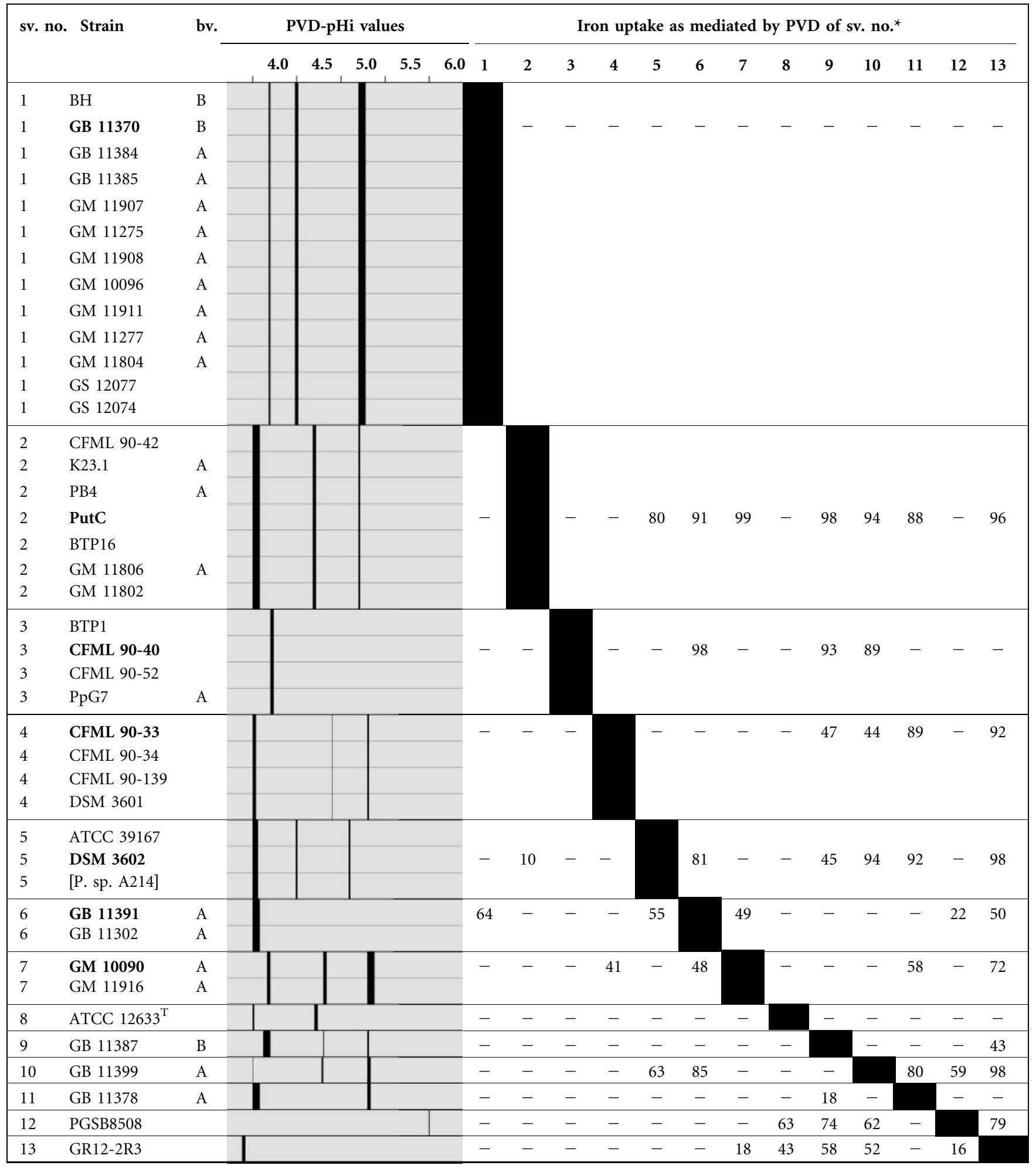

*Values are expressed in percentage of incorporation compared to the homologous system (100\%). For clarity, values below $10 \%$ (threshold limit) are replaced by a minus sign, while values of $100 \pm 15 \%$ are represented by a black square for the homologous uptakes. Values are middle means of at least two independent experiments. 
Table 3. Pseudomonas putida strains producing neutral pyoverdines and grouped into siderovars according to PVD-IEF profiles and PVD-mediated iron uptake specificity.

Some non-P. putida reference strains have been included. They are indicated by brackets. P. fl., P. fluorescens; P. j., P. jessenii; P. m., P. mandelii; P. sp., Pseudomonas sp. The CFML strains of siderovar 14 are now recognized as Pseudomonas monteilii (Elomari et al., 1997). Biovar assignation, if known, is indicated by the letter code A, B or C. PVD-pHi values of the PVD-isoform bands separated by isoelectrophoresis are indicated as bars with thickness proportional to the intensity of fluorescence demonstrated under UV-light illumination (see Fig. 1).

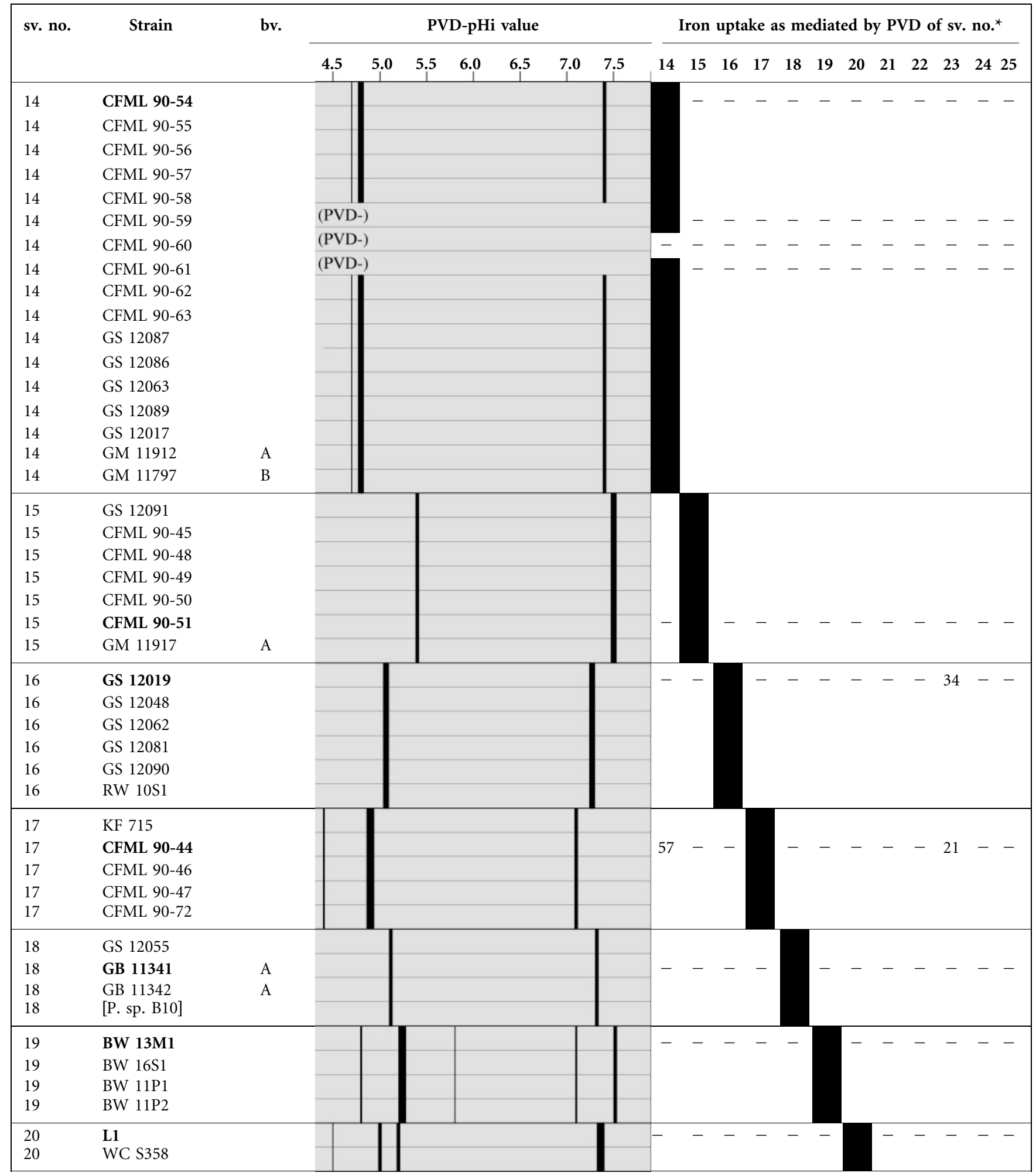


Table 3. cont.

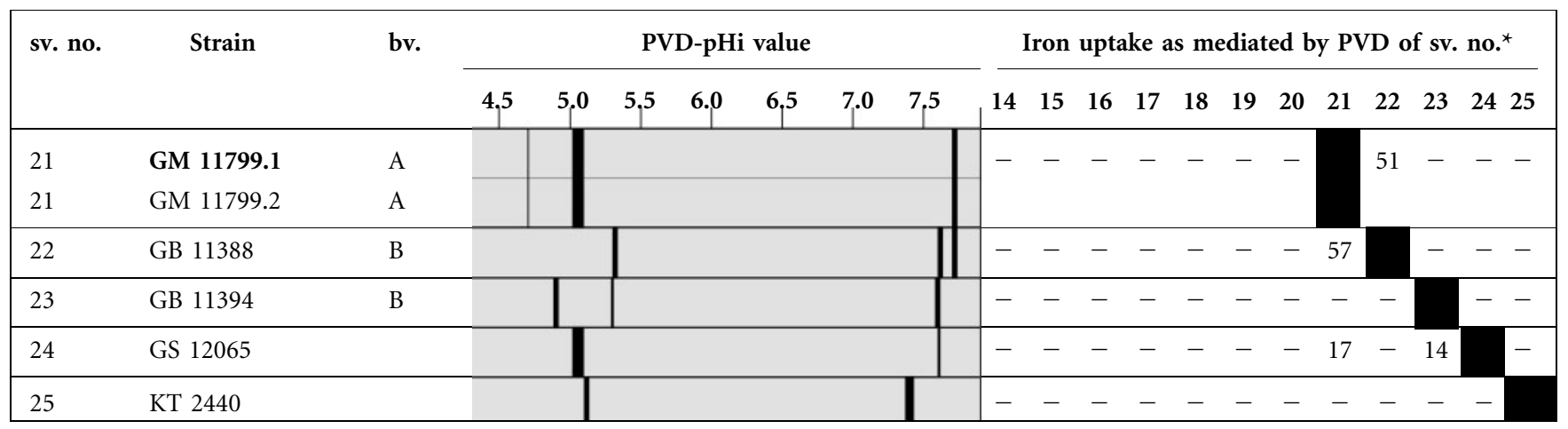

${ }^{\star}$ See footnote for Table 2 .

did not incorporate any of the pyoverdine-iron complexes and therefore could not be assigned to a siderotype.

Finally, based on both isoelectrophoresis and PVDmediated iron incorporation studies, a total of 35 siderovars was identified among the $144 \mathrm{P}$. putida strains. They are illustrated schematically in Tables 2, 3 and 4 on the basis of their acid, neutral and basic type pyoverdines, respectively. Within each table, siderovars are arranged in descending order according to the number of strains classified within each siderovars. For siderovars with more than one strain, a siderovar type strain, marked in bold typeface in Tables 2, 3 and 4, was chosen within each siderovar for pyoverdine purification and pyoverdinemediated iron incorporation studies.

\section{Siderovars with acidic pyoverdines}

Forty $P$. putida strains were characterized by acidic PVDIEF profiles, with bands usually ranging between $\mathrm{pHi} 3.9$ and 5.3 (Table 2). The pHi values, as well as the number of PVD-isoform bands, allowed the identification of 13 IEFgroups, with seven presenting three isoform bands, two having two bands and four being characterized by a unique pyoverdine band. Cross-incorporation studies correlated perfectly with the IEF-grouping. Within each group, strains were able to incorporate the ${ }^{59} \mathrm{Fe}$-pyoverdine of the type strain at around $100 \%$ efficiency, as indicated by black squares in the right panel of Table 2. Six siderovars were represented by only one strain, among them sv. 8 which included the type strain of $P$. putida ATCC $12633^{\mathrm{T}}$. The distribution of the other siderovars ranged from 13 strains for sv. 1 to two strains for sv. 6 and sv. 7. The structures of the pyoverdines characterized by siderovars $1,2,3,4,5$ and 8 are known and are shown in Table 5. When comparing the amino acid composition of their respective peptidic parts, no strong similarity could be seen, except that five of the pyoveridines are characterized by an Asp residue as the N-terminal amino acid branched to the chromophore. Another peculiarity concerns the pyoverdines of sv. 3 and sv. 4 , which are in fact isopyoverdines, i.e. pyoverdines with the peptide chain branched at the level of the C3 instead of the $\mathrm{Cl}$ of the chromophore (Budzikiewicz, 2004). The absence of pronounced structural correlations between these six pyoverdines is in agreement with their usually high level of specificity, as determined by heterologous pyoverdine-mediated iron uptake studies. As shown in Table 2, the pyoverdine characterizing sv. 3 was the most specific, since none of the strains from the other siderovars were able to use it in iron transport. Concerning strain specificity, heterologous uptake studies showed that some strains were highly specific, e.g. the strains of sv. 1 and sv. 8 , which were able to use only their own pyoverdine for iron transport. The other strains were able to use several acidic pyoverdines. Strain PutC of sv. 2 was able to use the largest number of foreign pyoverdines, being able to use seven with very high efficiency. Most of the structures of the pyoverdines with efficient heterologous uptake are presently unknown. Therefore, it cannot yet be decided whether the heterologous uptake is due to structural similarities between pyoverdines or to the presence of supplementary pyoverdine-receptors in these strains. Heterologous uptake studies involving a collection of structurally known pyoverdines (described in Fuchs et al., 2001) have concluded that each of the siderovars is characterized by an original pyoverdine; none of the pyoverdines of foreign origin belonging to the collection were able to mediate iron incorporation in these strains. One exception, however, concerned the pyoverdine of Pseudomonas sp. A214 which was used at $100 \%$ efficiency (data not shown) by the two P. putida strains belonging to sv. 5. As a control of pyoverdine identity, the two $P$. putida isolates of sv. 5 and Pseudomonas sp. A214, as shown in Table 2, middle panel, presented effectively an identical PVD-IEF pattern. It is noteworthy that $\operatorname{PVD}(\mathrm{A} 214)$ is the only one of these acidic pyoverdines in which the peptide chain does not begin with an Asp residue (Table 5).

\section{Siderovars with neutral pyoverdines}

Fifty strains of P. putida presenting PVD-IEF patterns with one to three isoform bands with acidic $\mathrm{pHi}$ values and one or two with neutral $\mathrm{pHi}$ values within the range of $\mathrm{pH} 4.0$ to $\mathrm{pH} 7.5$ were grouped in 12 siderovars (Table 3) according to their isoelectrophoretic and incorporation 
Table 4. Pseudomonas putida strains producing basic pyoverdines and grouped into siderovars according to PVD-IEF profiles and PVD-mediated iron uptake specificity.

Some non-P. putida reference strains have been included. They are indicated by brackets. P. fl., P. fluorescens; P. j., P. jessenii; P. m., P. mandelii; P. sp., Pseudomonas sp. The CFML strains of siderovar 27 are now recognized as Pseudomonas mosselii. Biovar assignation, if known, is indicated by the letter code A, B or C. PVD-pHi values of the PVD-isoform bands separated by isoelectrophoresis are indicated as bars with thickness proportional to the intensity of fluorescence demonstrated under UV-light illumination (see Fig. 1).

\begin{tabular}{|c|c|c|c|c|c|c|c|c|c|c|c|c|c|c|c|c|c|}
\hline \multirow{2}{*}{$\begin{array}{l}\text { Sv. } \\
\text { no. }\end{array}$} & \multirow[t]{2}{*}{ Strain } & \multirow[t]{2}{*}{ bv. } & \multicolumn{5}{|c|}{ PVD-pHi value } & \multicolumn{10}{|c|}{ Iron uptake as mediated by PVD of sv. no.* } \\
\hline & & & 7.5 & 8.0 & 8.5 & 9.0 & 9.5 & 26 & 27 & 28 & 29 & 30 & 31 & 32 & 33 & 34 & 35 \\
\hline 26 & D-LR223 & A & & & & & & & & & & & & & & & \\
\hline 26 & D-S824 & A & & & & & & & & & & & & & & & \\
\hline 26 & D-LR228 & A & & & & & & & & & & & & & & & \\
\hline 26 & D-LE3216 & A & & & & & & & & & & & & & & & \\
\hline 26 & D-S131 & A & & & & & & & & & & & & & & & \\
\hline 26 & D-TR331 & A & & & & & & & & & & & & & & & \\
\hline 26 & D-LRp414 & A & & & & & & & & & & & & & & & \\
\hline 26 & D-LRp212 & A & & & & & & & & & & & & & & & \\
\hline 26 & D-LE611 & A & & & & & & & & & & & & & & & \\
\hline 26 & D-LE711 & A & & & & & & & & & & & & & & & \\
\hline 26 & D-LRp 921 & A & & & & & & & & & & & & & & & \\
\hline 26 & GB 11379 & A & & & & & & & - & - & - & - & - & - & - & - & - \\
\hline 26 & GM 11274 & A & & & & & & & & & & & & & & & \\
\hline 26 & $9 \mathrm{~B} \mathrm{~W}$ & & & & & & & & & & & & & & & & \\
\hline 26 & [P. j. CFML 95-307 ] & & & & & & & & & & & & & & & & \\
\hline 27 & CFML 90-70 & & & & & & & & & & & & & & & & \\
\hline 27 & CFML 90-71 & & & & & & & & & & & & & & & & \\
\hline 27 & CFML 90-73 & & & & & & & & & & & & & & & & \\
\hline 27 & CFML 90-74 & & & & & & & & & & & & & & & & \\
\hline 27 & MF H2-127 & $\mathrm{C}$ & & & & & & & & & & & & & & & \\
\hline 27 & RW 5S2 & & & & & & & & & & & & & & & & \\
\hline 27 & BW $11 \mathrm{M} 1$ & & & & & & & & & & & & & & & & \\
\hline 28 & C-S111 & A & & & & & & & & & & & & & & & \\
\hline 28 & C-S413 & A & & & & & & & & & & & & & & & \\
\hline 28 & C-S215 & A & & & & & & & & & & & & & & & \\
\hline 28 & C-LRp214 & A & & & & & & & & & & & & & & & \\
\hline 28 & PGSB 8301 & & & & & & & & & & & & & & & & \\
\hline 28 & GS 12082 & & & & & & & - & - & & - & - & - & 88 & - & - & 35 \\
\hline 28 & [P. m. CFML 95-303 ] & & & & & & & & & & & & & & & & \\
\hline 29 & A10L & B & & & & & & & & & & & & & & & \\
\hline 29 & GB 11349 & B & & & & & & - & - & - & & - & - & - & - & - & - \\
\hline 29 & GB 11395 & B & & & & & & & & & & & & & & & \\
\hline $\begin{array}{l}29 \\
29\end{array}$ & $\begin{array}{l}\text { 10CW } \\
\text { [P. fl. ATCC 13525] }\end{array}$ & & & & & & & & & & & & & & & & \\
\hline
\end{tabular}


Table 4. cont.

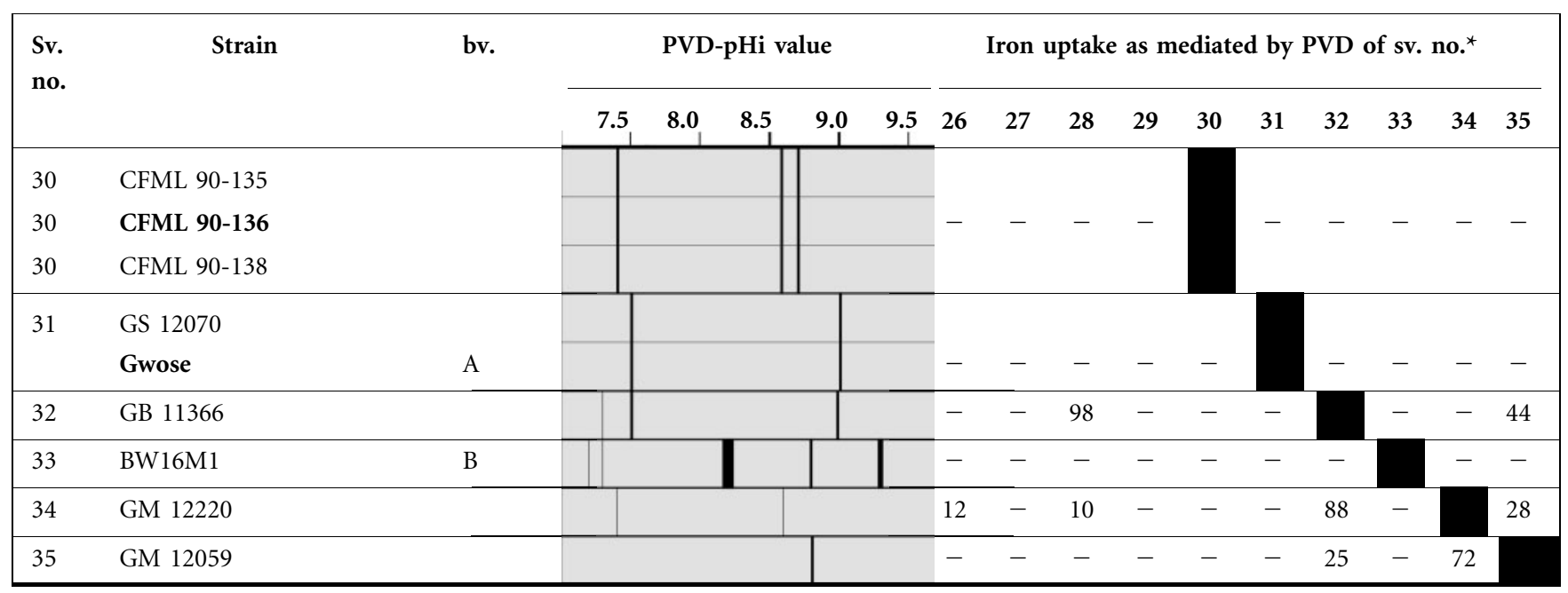

${ }^{\star}$ See footnote for Table 2 .

characteristics. The corresponding pyoverdines were highly specific in iron transport in addition to their producing strains, as only a very few heterologous uptakes were observed (Table 3, right panel). Among the six structurally known pyoverdines (Table 5, pyoverdines of siderovars 15 , $17,18,20,23$ and 25), one corresponded to an isopyoverdine [PVD(CFML 90-44) of sv. 17], whereas three had Asp as the N-terminal amino acid of their respective peptide chain. Siderovar 14, the most important siderovar as determined by the number of strains (17), was formed by strains that originated from three different collections. Interestingly, the CFML strains of sv. 14, first identified as isolates of $P$. putida, have been since recognized as representatives of a novel species, Pseudomonas monteilii (Elomari et al., 1997). Thus, the pyoverdine of sv. 14 was assigned to Pseudomonas monteilii and consequently the other strains of sv. 14 could be expected to also belong to this species. Heterologous uptakes involving the collection of structurally known pyoverdines showed that 10 of the 12 neutral pyoverdines were highly specific to their respective producing strains, while pyoverdines produced by strains of sv. 18 and sv. 23 corresponded to the pyoverdines of Pseudomonas sp. B10 (Teintze et al., 1981) and P. fluorescens PL7 (Barelmann et al., 2002), respectively.

\section{Siderovars with alkaline pyoverdines}

According to PVD-IEF patterns and cross-uptakes, 10 siderovars were obtained from 54 strains of $P$. putida presenting alkaline profiles for their respective pyoverdines, i.e. in most cases (Table 4, middle panel), one or two isoform-bands at pHi values between 7.0 and 8.0 and one or two isoform-bands at pHi values higher than 8.0. The predominant siderovar, sv. 26, containing 21 strains originating from five collections, was characterized, thanks to PVD-IEF and heterologous uptake studies, by the production of a pyoverdine identical to the one already described for $P$. fluorescens 9AW and for P. putida 9BW (Budzikiewicz et al., 1997). Furthermore, this pyoverdine was later associated with the species P. jessenii (Meyer et al., 2002). The second siderovar in size (sv. 27, 15 strains originating from three collections) was for similar reasons correlated with $P$. mosselii, while the third (sv. 28) corresponded to the siderotype of $P$. mandelii (Meyer et al., 2002). Two other siderovars, sv. 29 and sv. 34, were shown to correspond to pyoverdines characterizing the type strains of $P$. fluorescens and P. chlororaphis for sv. 29 and P. fluorescens strain PL8 for sv. 34 (Hohlneicher et al., 1995; Barelmann et al., 2002). In contrast to the situation found for the two other pyoverdine groups, none of the structurally known pyoverdines produced by these strains started their $\mathrm{NH}_{2}$-terminal peptidic part with an Asp residue. Finally, as for the neutral pyoverdines, a high specificity of recognition was usually the rule between strains and their respective pyoverdines, as can be deduced from the low number of cross-incorporations detailed in Table 4, right panel.

\section{Correlations between siderovars and bacterial species}

Among $P$. putida isolates, some have been reclassified into novel species, namely $P$. monteilii (Elomari et al., 1997) and P. mosselii (Dabboussi et al., 2002). The DNA-DNA hybridization values between the strains used in the present study and these two species are reported in Table 6 (strains CFML $90-60^{\mathrm{T}}$ and CFML $90-83^{\mathrm{T}}$ for $P$. monteilii and $P$. mosselii, respectively). Additional hybridization data obtained with the DNAs of strains ATCC $12633^{\mathrm{T}}$ (representative of phenon IIb, ribotype G), CFML 90-48 (phenon IIb, ribotype E), CFML 90-136 (phenon IId, ribotype B) and CFML 90-34 (phenon IIa, ribotype A) are also reported. DNA from strains belonging to these 
Table 5. Pyoverdine structure and species correlation characterizing some of the Pseudomonas putida siderovars

Dab, Diaminobutyric acid; OHAsp, threo- $b$-hydroxy-Asp; OHHis, threo- $b$-hydroxy-His; OHOrn, $d \mathrm{~N}$-hydroxy-Orn, AOHOrn, $d \mathrm{~N}$-acetyl-OHOrn; BOHOrn, $d \mathrm{~N}$-butyryl-OHOrn; FOHOrn, $d \mathrm{~N}$-formyl-OHOrn; cOHOrn, cyclo-OHOrn (3-amino-1-hydroxy-piperidone-2); aThr, allo-Thr. Damino acids are underlined. Half of the serine residues in PVD(ATCC $12633^{\mathrm{T}}$ ) and PVD(CFML 90-44) are of the D-form, but with enantiomer positions not determined (Budzikiewicz, 2004).

\begin{tabular}{|c|c|c|c|c|c|}
\hline $\begin{array}{l}\text { sv. } \\
\text { no. }\end{array}$ & $\begin{array}{l}\text { sv. type } \\
\text { strain }\end{array}$ & PVD-peptide structure ${ }^{\star}$ & $\begin{array}{l}\text { Identity with } \\
\text { PVD-type }\end{array}$ & $\begin{array}{l}\text { Species affiliation of the } \\
\text { PVD-type }\end{array}$ & Reference \\
\hline 1 & GB 11370 & $\begin{array}{l}\text { Asp-Lys-OHAsp-Ser-Ala-Ser- } \\
\text { cOHOrn }\end{array}$ & G176 (=GB 11370) & P. putida & Budzikiewicz et al. (1999) \\
\hline 2 & PutC & $\begin{array}{l}\text { Asp-BOHOrn-Dab-Thr-Gly- } \\
\text { Ser-Ser-OHAsp-aThr }\end{array}$ & PutC & P. putida & Seinsche et al. (1993) \\
\hline 3 & CFML 90-40 & $\begin{array}{l}\text { Asp-Ala-Asp-AOHOrn-Ser- } \\
\text { cOHOrn }\end{array}$ & $\begin{array}{l}\text { BTP1 }(=\text { CFML } \\
90-40)\end{array}$ & P. putida & Jacques et al. (1995) \\
\hline 4 & CFML 90-33 & $\begin{array}{l}\text { Asp-Lys-Thr-OHAsp-Thr- } \\
\text { aThr-cOHOrn }\end{array}$ & CFML 90-33 & P. putida & Sultana et al. (2001b) \\
\hline 5 & DSM 3602 & $\begin{array}{l}\text { Ser-AOHOrn-Ala-Gly } \\
\text { (Ser-Ala-OHAsp-Thr) }\end{array}$ & A214 & Pseudomonas sp. & Uria-Fernandez et al. (2003) \\
\hline 8 & ATCC $12633^{\mathrm{T}}$ & $\begin{array}{l}\text { Asp-Lys-OHAsp-Ser-Thr-Ala- } \\
\text { Glu-Ser-cOHOrn }\end{array}$ & ATCC $12633^{\mathrm{T}}$ & P. putida & Persmark et al. (1990) \\
\hline 15 & CFML 90-51 & $\begin{array}{l}\text { Asp-Lys-OHAsp-Ser-Gly aThr- } \\
\text { Lys-cOHOrn }\end{array}$ & CFML 90-51 & P. putida & Sultana et al. (2000) \\
\hline 17 & CFML 90-44 & $\begin{array}{l}\text { Asp-Lys-AOHOrn-Thr-Ser-Ser-Gly } \\
\text { Ser-Ser-cOH } \underline{\text { Orn }}\end{array}$ & CFML 90-44 & P. putida & Sultana et al. (2001a) \\
\hline 18 & GB 11341 & Lys-OHAsp-Ala-aThr-Ala-cOHOrn & $\mathrm{B} 10$ & Pseudomonas sp. & Teintze et al. (1981) \\
\hline 20 & L1 & $\begin{array}{l}\text { Asp-Lys-OHAsp-Ser-aThr-Ala- } \\
\text { Thr-Lys-cOHOrn }\end{array}$ & L1 & P. putida & Uria-Fernandez et al. (2003) \\
\hline 23 & GB 11394 & $\begin{array}{l}\text { Ser-AOHOrn-Ala-Gly } \\
\text { aThr-Ala-cOHOrn }\end{array}$ & PL7 & P. fluorescens $b v . V$ & Barelmann et al. (2002) \\
\hline 25 & KT2440 & $\begin{array}{l}\text { OHAsp-Lys-OHAsp-Dab-Gly } \\
\text { Ser-cOHOrn* }\end{array}$ & KT2440 & P. putida & Ravel \& Cornelis (2003) \\
\hline 26 & GB 11379 & 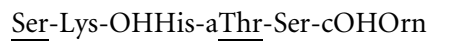 & 9AW & P. fluorescens/P. jessenii & Budzikiewicz et al. (1997) \\
\hline 28 & GS 12082 & Ala-Lys-Thr-Ser-AOHOrn-cOHOrn & SB8.3 & P. fluorescens/P. mandelii & Budzikiewicz et al. (1992) \\
\hline 29 & GB 11349 & $\begin{array}{l}\text { Ser-Lys-Gly FOHOrn-c(Lys- } \\
\text { FOHOrn-Ser) }\end{array}$ & ATCC 13525 & P. fluorescens bv. I & Hohlneicher et al. (1995) \\
\hline 31 & Gwose & $\begin{array}{l}\text { Ser-Thr-Ser-Orn-OHAsp- } \\
\text { (Gln-Dab)-Ser-aThr-cOHOrn }\end{array}$ & Gwose & P. putida & Gwose \& Taraz (1992) \\
\hline 34 & GM 12220 & $\begin{array}{l}\text { Lys-AOHOrn-Ala-Gly } \\
\text { aThr-Ser-cOHOrn }\end{array}$ & PL8 & P. fluorescens $b v . V$ & Barelmann et al. (2002) \\
\hline
\end{tabular}

${ }^{\star}$ Hypothetical structure without amino acid stereochemistry based on in silico studies of genome sequences in P. putida KT2440 (Ravel \& Cornelis, 2003).

phenotypic groups was also hybridized against the labelled DNA of these six strains. As shown in Table 6, the strain groupings obtained by siderotyping correlated perfectly for a large majority of strains, with a clustering based on phenotypic features or DNA-DNA hybridization. Phenons IIc and IV, corresponding to the P. monteilii and P. mosselii species, respectively, formed well-circumscribed DNADNA relatedness groups and also formed well-characterized siderovars as shown in Tables 3 and 4 (sv. 14 and sv. 27). The same conclusion was reached for the three strains of phenon IIb, ribotype E, which formed a separate DNADNA hybridization group and produced an identical pyoverdine (sv. 15). Moreover, the two separate phenons
IIa and IId, which would be expected to correspond to very closely related strains according to their DNA-DNA hybridization values (Table 6) were, nevertheless, distinguished as two separate siderovars by siderotyping. The ATCC $12633^{\mathrm{T}}$ hybridization group, however, included seven strains that were characterized by four different siderovars (sv. 8 and sv. 15 for one strain each, sv. 17 for two strains and sv. 3 for three strains). Thus, while many clusters and species each corresponded to a specific siderovar, the species Pseudomonas putida sensu stricto should presently be seen as a group of strains characterized by at least four siderovars, with the sv. 15 siderotype being shared with another closely related taxonomic group. Such siderovar 
Table 6. Correlations between siderotyping and DNA-DNA hybridization for strains grouped according to phenotyping and ribotyping

Values in bold type show the grouping of strains in species according to the DNA-DNA hybridization method (values between 70 and $100 \%$ ). Phenotyping and ribotyping are according to Elomari et al. (1994) and Dabboussi et al. (2002).

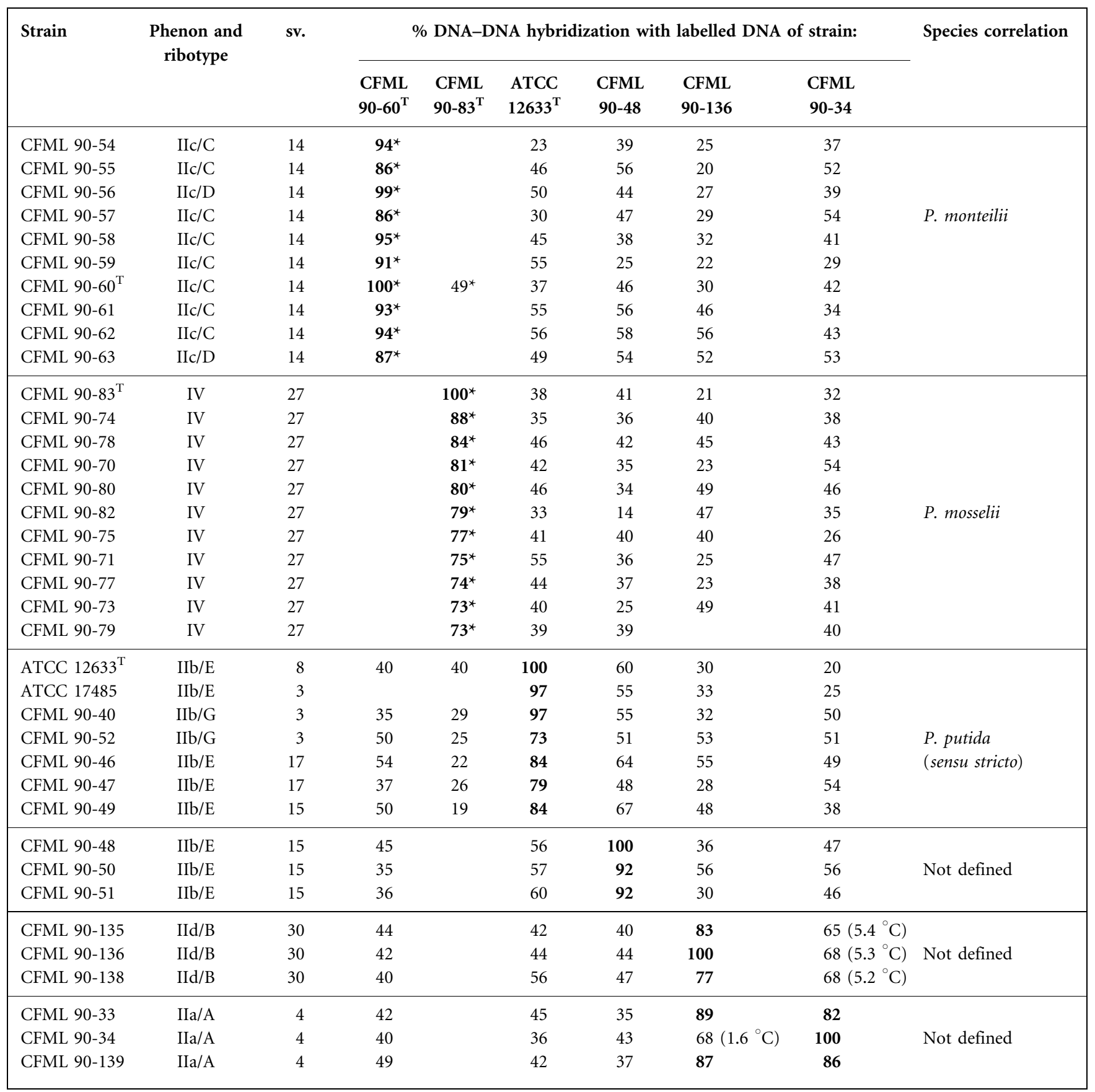

${ }^{\star}$ Hybridization values are taken from Elomari et al. (1997) and Dabboussi et al. (2002).

multiplicity within one species, although not common, has already been described for Pseudomonas aeruginosa (Meyer et al., 1997) and for Pseudomonas lini (Delorme et al., 2002).
On the other hand, strains belonging to different species but sharing identical pyoverdines have also been described (Hohlneicher et al., 1995). 


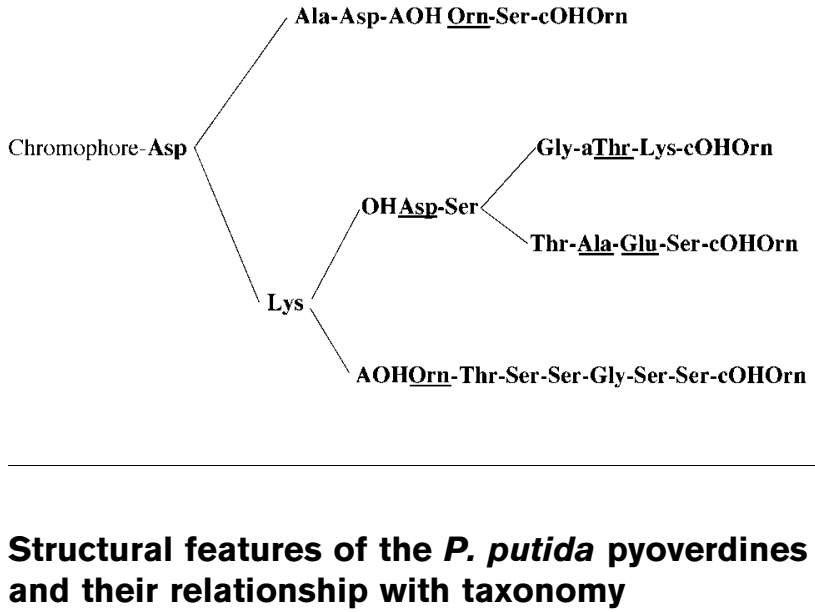

Of the 35 pyoverdines identified within the collection of $P$. putida strains, 16 are already structurally known. Their respective peptide chains are described in Table 5. In addition, the KT2440 pyoverdine, with a peptidic part deduced from a genomic analysis rather than a chemical analysis (Ravel \& Cornelis, 2003), has been included in Table 5. From a comparison of these structures, several major features can be identified:

(i) with the exception of the pyoverdine produced by $P$. putida strain Gwose of sv. 31, only pyoverdines produced by strains of $P$. putida (nine strains marked in bold type in Table 5) present an aspartyl residue [hydroxy-aspartyl for $\operatorname{PVD}(\mathrm{KT} 2440)]$ as the N-terminal amino acid directly linked to the chromophore;

(ii) pronounced structural similarities exist between many pyoverdines of $P$. putida with, for instance, six pyoverdines (of sv. 1, 4, 8, 15, 17, 20) have a Lys following Asp and among them, four (sv. 1, 8, 15, 20) present the same Asp-LysOHAsp-Ser sequence that begins the peptidic part containing 7 to 9 amino acid residues, depending on the strain;

(iii) when focusing on the pyoverdines that characterize the four siderovars of the species $P$. putida sensu stricto, namely PVD(CFML 90-40) of sv. 3, PVD(ATCC $12633^{\mathrm{T}}$ ) of sv. 8, PVD(CFML 90-51) of sv. 15 and PVD(CFML 90-44) of sv. 17, structural relationships between the four compounds can be established by a dichotomic tree based on the primary sequences of the different peptide chains as illustrated in Fig. 2. As the biosynthesis of pyoverdines implies amino-acyl specific domains within multi-functional peptide synthetases (Ravel \& Cornelis, 2003), it can be assumed that strains producing structurally related pyoverdines should contain common DNA sequences corresponding to common amino-acyl specific domains and thus such strains should be phylogenetically related. Thus, siderovar multiplicity within the species $P$. putida sensu stricto could be seen as the result of gene evolution particularly affecting the peptide synthetase genes involved in pyoverdine biosynthesis;

(iv) the other pyoverdines that do not begin with Asp as the N-terminal amino acid, but with Ala for sv. 28, Lys for
PVD(CFML 90-40)

(sv. 3)

PVD(CFML 90-51) (sv. 15)

PVD(ATCC 12633) (sv, 8)

PVD(CFML 90-44) (sv. 17)
Fig. 2. Structural phylogeny among the pyoverdines of strains belonging to the species Pseudomonas putida sensu stricto. For explanation of the abbreviations, see the footnote for Table 5. sv. 18 and sv. 34, or D-Ser for four siderovars (sv. 5, 23, 26, 29 ), actually corresponded to compounds first described as produced by strains of $P$. fluorescens (sv. 23, 26, 28, 29, 34) or by strains with no defined species attribution (sv. 5 and sv. 18) (Table 5). Among these siderovars, three (sv. 23, 29 and 34) are formed exclusively by strains identified as $P$. putida biovar B. The other siderovars (sv. 5, 18, 26, 28) contain many strains belonging (when known) to biovar A, among them a majority of strains sharing the same siderotype as $P$. jessenii (sv. 26) or P. mandelii (sv. 28) (Verhille et al., 1999).

Thus, siderotyping allows the recognition of a major core of siderovars, i.e. the Asp-pyoverdine group, corresponding to taxa with strong phylogenetic relationships and with some of them even included within the same taxon, i.e. the species $P$. putida sensu stricto. Other siderovars corresponded to clusters which remain to be defined as novel species according to phenotyping, ribotyping and DNA-DNA hybridization, e.g. phenons IIa/A (sv. 4), IId/B (sv. 30) and IIb/E with strains CFML 90-48, 90-50 and 90-51 (sv. 15). In addition, a second group, including siderovars correlating to more distantly related species such as $P$. jessenii and $P$. mandelii and also including siderovars closely related to the species $P$. fluorescens, was recognized among the collection of strains analysed. In the majority of cases, the P. putida isolates received as biovar A fell in siderovars which characterized the first group and part of the second group, e.g. sv. 26 and sv. 28 corresponding to P. jessenii and $P$. mandelii. In contrast, $P$. putida biovar B strains preferentially contributed to the siderovars of the second group related to the $P$. fluorescens lineage, a correlation that is in full agreement with the numerous taxonomical studies that state that $P$. putida biovar B strains are phylogenetically closer to P. fluorescens than to P. putida biovar A strains (Stanier et al., 1966; Yamamoto \& Harayama, 1998; Yamamoto et al., 2000; Hilario et al., 2004).

\section{ACKNOWLEDGEMENTS}

The authors are indebted to L. Gardan, P. Lemanceau, S. Harayama, A. Parret, R. De Mot, P. Jacques, H. Budzikiewicz, S. Shivaji and M. Feuilloley for the gift of strains. J. Lalucat and N. J. Palleroni are deeply acknowledged for their helpful critical reading and improvement of the manuscript. 


\section{REFERENCES}

Anzai, Y., Kim, H., Park, J.-Y., Wakabayashi, H. \& Oyaizu, H. (2000). Phylogenetic affiliation of the pseudomonads based on 16S rRNA sequence. Int J Syst Evol Microbiol 50, 1563-1589.

Barelmann, I., Taraz, K., Budzikiewicz, H., Geoffroy, V. A. \& Meyer, J.-M. (2002). The structures of the pyoverdins from two Pseudomonas fluorescens strains accepted mutually by their respective producers. $Z$ Naturforsch [C] 57, 9-16.

Barrett, E. L., Solanes, R. E., Tang, J. S. \& Palleroni, N. J. (1986). Pseudomonas fluorescens biovar V: its resolution into distinct component groups and the relationship of these groups to other $P$. fluorescens biovars, to $P$. putida, and to psychrotrophic pseudomonads associated with food spoilage. J Gen Microbiol 132, 2709-2721.

Bossis, E. (1995). Les Pseudomonas fluorescents de la rhizosphère: étude taxonomique et effets sur la croissance de la tomate et du maïs, de la germination à la levée, p. 143. PhD thesis, Université de Nantes, France.

Bossis, E., Lemanceau, P., Latour, X. \& Gardan, L. (2000). The taxonomy of Pseudomonas fluorescens and Pseudomonas putida: current status and need for revision. Agronomie 20, 51-63.

Bouallegue, O., Mzoughi, R., Weill, F. X., Mahdhaoui, N., Ben Salem, Y., Sboui, H., Grimont, F. \& Grimont, P. A. D. (2004). Outbreak of Pseudomonas putida bacteremia in a neonatal intensive care unit. J Hosp Infect 57, 88-91.

Brosch, R., Lefèvre, M., Grimont, F. \& Grimont, P. A. D. (1996). Taxonomic diversity of pseudomonads revealed by computerinterpretation of ribotyping data. Syst Appl Microbiol 19, 541-555.

Budzikiewicz, H. (2004). Siderophores of the Pseudomonadaceae sensu stricto (fluorescent and non-fluorescent Pseudomonas spp.). Fortschr Chem Org Naturst 87, 81-237.

Budzikiewicz, H., Schröder, H. \& Taraz, K. (1992). Zur biogenese der Pseudomonas-siderophore: der nachweis analoger strukturen eines pyoverdin-desferribactin-paares. $Z$ Naturforsch [C] 47, 26-32.

Budzikiewicz, H., Kilz, S., Taraz, K. \& Meyer, J.-M. (1997). Identical pyoverdines from Pseudomonas fluorescens $9 \mathrm{AW}$ and from Pseudomonas putida 9BW. Z Naturforsch [C] 52, 721-728.

Budzikiewicz, H., Fernandez, D. U., Fuchs, R., Michalke, R., Taraz, K. \& Ruangviriyachai, C. (1999). Pyoverdines with a Lys $\varepsilon$-amino link in the peptide chain? Z Naturforsch [C] 54, 1021-1026.

Bultreys, A., Gheysen, I., Maraite, H. \& De Hoffmann, E. (2001). Characterization of fluorescent and non fluorescent peptide siderophores produced by Pseudomonas syringae strains and their potential use in strain identification. Appl Environ Microbiol 67, $1718-1727$.

Buyer, J. S., Wright, J. M. \& Leong, J. (1986). Structure of pseudobactin A214, a siderophore from a bean-deleterious Pseudomonas. Biochemistry 25, 5492-5499.

Crosa, J. H., Brenner, D. J. \& Falkow, S. (1973). Use of a singlestrand-specific nuclease for analysis of bacterial and plasmid deoxyribonucleic acid homo- and heteroduplexes. J Bacteriol 115, 904-911.

Dabboussi, F., Hamze, M., Singer, E., Geoffroy, V., Meyer, J.-M. \& Izard, D. (2002). Pseudomonas mosselii sp. nov., a novel species isolated from clinical specimens. Int J Syst Evol Microbiol 52, 363-376.

Dawson, S. L., Fry, J. C. \& Dancer, B. N. (2002). A comparative evaluation of five typing techniques for determining the diversity of fluorescent pseudomonads. J Microbiol Methods 50, 9-22.

Delorme, S., Lemanceau, P., Christen, R., Corberand, T., Meyer, J.-M. \& Gardan, L. (2002). Pseudomonas lini sp. nov., a novel species from bulk and rhizospheric soils. Int J Syst Evol Microbiol 52, 513-523.
Elomari, M., Izard, D., Vincent, P., Coroler, L. \& Leclerc, H. (1994). Comparison of ribotyping analysis and numerical taxonomy studies of Pseudomonas putida biovar A. Syst Appl Microbiol 17, 361-369.

Elomari, M., Coroler, L., Hoste, B., Gillis, M., Izard, D. \& Leclerc, H. (1996). DNA relatedness among Pseudomonas strains isolated from natural mineral waters and proposal of Pseudomonas veronii sp. nov. Int J Syst Bacteriol 46, 1138-1144.

Elomari, M., Coroler, L., Verhille, S., Izard, D. \& Leclerc, H. (1997). Pseudomonas monteilii sp. nov., isolated from clinical specimens. Int J Syst Bacteriol 47, 846-852.

Fuchs, R., Schäfer, M., Geoffroy, V. \& Meyer, J.-M. (2001). Siderotyping - a powerful tool for the characterization of pyoverdines. Curr Top Med Chem 1, 31-57.

Grimont, P. A. D., Popoff, M. Y., Grimont, F., Coynault, C. \& Lemelin, M. (1980). Reproducibility and correlation study of three deoxyribonucleic acid hybridization procedures. Curr Microbiol 4, 325-330.

Grimont, P. A. D., Vancanneyt, M., Lefevre, M., Vandemeulebroecke, K., Vauterin, L., Brosch, R., Kersters, K. \& Grimont, F. (1996). Ability of Biolog and Biotype-100 systems to reveal the taxonomic diversity of the pseudomonads. Syst Appl Microbiol 19, 510-527.

Gwose, I. \& Taraz, K. (1992). Pyoverdine aus Pseudomonas putida. $Z$ Naturforsch [C] 47, 487-502.

Hilario, E., Buckley, T. R. \& Young, J. M. (2004). Improved resolution on the phylogenetic relationships among Pseudomonas by the combined analysis of atpD, carA, recA and $16 \mathrm{~S}$ rDNA. Antonie van Leeuwenhoek 86, 51-64.

Hohlneicher, U., Hartmann, R., Taraz, K. \& Budzikiewicz, H. (1995). Pyoverdin, ferribactin, azotobactin - a new triade of siderophores from Pseudomonas chlororaphis ATCC 9446 and its relation to Pseudomonas fluorescens ATCC 13525. Z Naturforsch [C] 50, 337-344.

Jacques, P., Ongena, M., Gwose, I., Seinsche, D., Schröder, H., Delfosse, P., Thonart, P., Taraz, K. \& Budzikiewicz, H. (1995). Structure and characterization of isopyoverdin from Pseudomonas putida BTP1 and its relation to the biogenetic pathway leading to pyoverdins. Z Naturforsch [C] 50, 622-629.

Latour, X., Corberand, T., Laguerre, G., Allard, F. \& Lemanceau, P. (1996). The composition of fluorescent pseudomonad populations associated with roots is influenced by plant and soil type. Appl Environ Microbiol 62, 2449-2456.

Lemanceau, P., Corberand, T., Gardan, L., Latour, X., Laguerre, G., Boeufgras, J. M. \& Alabouvette, C. (1995). Effect of two plant species, Flax (Linum usitatissinum L.) and tomato (Lycopersicon esculentum Mill.), on the diversity of soilborne populations of fluorescent pseudomonads. Appl Environ Microbiol 61, 1004-1012.

Mattar, J. (1993). Les Pseudomonas fluorescents de la rhizosphère: caractérisation, incidence de la température et de la microflore autochtone sur la colonisation racinaire, p. $87 . \mathrm{PhD}$ thesis, Université de Lyon I, France.

Meyer, J.-M. (2000). Pyoverdines: pigments, siderophores and potential taxonomic markers of fluorescent Pseudomonas species. Arch Microbiol 174, 135-142.

Meyer, J.-M. \& Geoffroy, V. (2004). Environmental fluorescent Pseudomonas and pyoverdine diversity: how siderophores could help microbiologists in bacterial identification and taxonomy. In Iron Transport in Bacteria, pp. 451-468. Edited by J. H. Crosa, A. R. Mey \& S. M. Payne. Washington, DC: American Society for Microbiology.

Meyer, J.-M., Stintzi, A., De Vos, D., Cornelis, P., Tappe, R., Taraz, K. \& Budzikiewicz, H. (1997). Use of siderophores to type pseudomonads: the three Pseudomonas aeruginosa pyoverdine systems. Microbiology 143, 35-43. 
Meyer, J.-M., Geoffroy, V. A., Baida, N., Gardan, L., Izard, D., Lemanceau, P., Achouak, W. \& Palleroni, N. J. (2002). Siderophore typing, a powerful tool for the identification of fluorescent and non-fluorescent Pseudomonas. Appl Environ Microbiol 68, 2745-2753.

Moore, E. R. B., Mau, M., Arnscheidt, A., Böttger, E. C., Hutson, R. A., Collins, M. D., Van De Peer, Y., De Wachter, R. \& Timmis, K. N. (1996). The determination and comparison of the 16S rRNA gene sequences of species of the genus Pseudomonas (sensu stricto) and estimation of the natural intrageneric relationships. Syst Appl Microbiol 19, 478-492.

Palleroni, N. J. (1984). Genus I. Pseudomonas Migula 1894. In Bergey's Manual of Systematic Bacteriology, vol. 1, pp. 141-199. Edited by N. R. Krieg \& J. G. Holt. Baltimore: Williams and Wilkins.

Palleroni, N. J. (1993). Pseudomonas classification. A new case history in the taxonomy of gram-negative bacteria. Antonie van Leeuwenhoek 64, 231-251.

Palleroni, N. J. (2005). Pseudomonas. In Bergey's Manual of Systematic Bacteriology, 2nd edn, Part B, The Gammaproteobacteria. pp. 323-379. Edited by G. M. Garrity, D. J. Brenner, N. R. Krieg \& J. T. Staley. New York: Springer.

Parret, A. H. A. \& De Mot, R. (2000). Bacteriocin production by rhizosphere-colonizing fluorescent Pseudomonas. In Proceedings of the 5th International PGPR Workshop, Cordoba, Argentina.

Persmark, M., Frejd, T. \& Mattiasson, B. (1990). Purification, characterization, and structure of pseudobactin 589A, a siderophore from a plant growth promoting Pseudomonas. Biochemistry 29, 7348-7356.

Perz, J. F., Craig, A. S., Stratton, C. W., Bodner, S. J., Phillips, W. E., Jr \& Schaffner, W. (2005). Pseudomonas putida septicemia in a special care nursery due to contaminated flush solution prepared in a hospital pharmacy. J Clin Microbiol 43, 5316-5318.

Ravel, J. \& Cornelis, P. (2003). Genomics of pyoverdine-mediated iron uptake in pseudomonads. Trends Microbiol 11, 195-200.

Seinsche, D., Taraz, K., Budzikiewicz, H. \& Gondol, D. (1993). Neue pyoverdin-siderophore aus Pseudomonas putida C. J Prakt Chem Chem-Ztg 335, 157-168.

Shivaji, S., Rao, N. S., Saisree, L., Shet, V., Reddy, G. S. N. \& Bhargava, P. M. (1989). Isolation and identification of Pseudomonas spp. from Schirmacher Oasis, Antarctica. Appl Environ Microbiol 55, 767-770.

Spilker, T., Coenye, T., Vandamme, P. \& LiPuma, J. J. (2004). PCRbased assay for differentiation of Pseudomonas aeruginosa from other Pseudomonas species recovered from cystic fibrosis patients. J Clin Microbiol 42, 2074-2079.

Stanier, R. Y., Palleroni, N. J. \& Doudoroff, M. (1966). The aerobic pseudomonads: a taxonomic study. J Gen Microbiol 43, 159-271.
Sultana, R., Siddiqui, B. S., Taraz, K., Budzikiewicz, H. \& Meyer, J.-M. (2000). A pyoverdine from Pseudomonas putida CFML 90-51 with a Lys $\varepsilon$-amino link in the peptide chain. Biometals 13, 147-152.

Sultana, R., Siddiqui, B. S., Taraz, K., Budzikiewicz, H. \& Meyer, J.-M. (2001a). An isopyoverdin from Pseudomonas putida CFML 90-44. Z Naturforsch [C] 56, 303-307.

Sultana, R., Siddiqui, B. S., Taraz, K., Budzikiewicz, H. \& Meyer, J.-M. (2001b). An isopyoverdin from Pseudomonas putida CFML 90-33. Tetrahedron 57, 1019-1023.

Sutra, L., Risède, J. M. \& Gardan, L. (2000). Isolation of fluorescent pseudomonads from the rhizosphere of banana plants antagonistic towards root necrosing fungi. Lett Appl Microbiol 31, 289-293.

Teintze, M., Hossain, M. B., Barnes, C. L., Leong, J. \& van der Helm, D. (1981). Structure of ferric pseudobactin, a siderophore from a plant growth promoting Pseudomonas. Biochemistry 20, 6446-6457.

Tesar, M., Hoch, C., Moore, E. R. B. \& Timmis, K. N. (1996). Westprinting: development of a rapid immunochemical identification for species within the genus Pseudomonas sensu stricto. Syst Appl Microbiol 19, 577-588.

Timmis, K. N. (2002). Pseudomonas putida: a cosmopolitan opportunist par excellence. Environ Microbiol 4, 779-781.

Uria-Fernandez, D., Geoffroy, V., Schäfer, M., Meyer, J.-M. \& Budzikiewicz, H. (2003). Structure revision of several pyoverdins produced by plant-growth promoting and plant-deleterious Pseudomonas species. Monatsh Chem 134, 1421-1431.

Vancanneyt, M., Torck, U., Dewettinck, D., Vaerewijck, M. \& Kersters, K. (1996). Grouping of pseudomonads by SDS-PAGE of whole-cell proteins. Syst Appl Microbiol 19, 556-568.

Vandamme, P., Pot, B., Gillis, M., De Vos, P., Kersters, K. \& Swings, J. (1996). Polyphasic taxonomy, a consensus approach to bacterial systematics. Microbiol Rev 60, 407-438.

Verhille, S., Baida, N., Dabboussi, F., Izard, D. \& Leclerc, H. (1999). Taxonomic study of bacteria isolated from natural mineral waters: proposal of Pseudomonas jessenii sp. nov. and Pseudomonas mandelii sp. nov. Syst Appl Microbiol 22, 45-58.

Yamamoto, S. \& Harayama, S. (1995). PCR amplification and direct sequencing of $g y r B$ genes with universal primers and their application to the detection and taxonomic analysis of Pseudomonas putida strains. Appl Environ Microbiol 61, 1104-1109.

Yamamoto, S. \& Harayama, S. (1998). Phylogenetic relationships of Pseudomonas putida strains deduced from the nucleotide sequences of gyrB, rpoD and 16 rRNA genes. Int J Syst Bacteriol 48, 813-819.

Yamamoto, S., Kasai, H., Arnold, D. L., Jackson, R. W., Vivian, A. \& Harayama, S. (2000). Phylogeny of the genus Pseudomonas: intrageneric structure reconstructed from the nucleotide sequences of gyrB and rpoD genes. Microbiology 146, 2385-2394. 